\title{
EPITHERMAL NEUTRON ACTIVATION ANALYSIS FOR BACTERIAL TRANSFORMATIONS OF CHROMIUM
}

\author{
N.Ya. Tsibakhashvili ${ }^{1,2}$, L. Mosulishvili ${ }^{1}$, E. Kirkesali ${ }^{1}$, T. Kalabegishvili ${ }^{1,2}$, S. Kerkenjia ${ }^{2}$, \\ M.V. Frontasyeva ${ }^{3}$, Gh. Duca ${ }^{4}$, I. Zinicovscaia ${ }^{3,4}$ \\ ${ }^{I}$ Andronikashvili Institute of Physics, Tbilisi, Georgia, \\ ${ }^{2}$ Chavchavadze State University, Tbilisi, Georgia \\ ${ }^{3}$ Frank Laboratory of Neutron Physics, Joint Institute for Nuclear Research,Dubna,Russia \\ ${ }^{4}$ University of the Academy of Sciences of Moldova \\ E-mail: zing@nf.jinr.ru
}

\begin{abstract}
Most powerful primary analytical technique, neutron activation analysis, was applied to study indigenous bacteria, namely, Arthrobacter genera which can be successfully used in detoxification and immobilization of toxic substances. In the present study the effect of $\operatorname{Cr}(\mathrm{VI})$ on the elemental content of these bacteria has been examined. The concentrations from 12 to 19 elements such as $\mathrm{Na}, \mathrm{Al}, \mathrm{Cl}, \mathrm{K}, \mathrm{Fe}, \mathrm{Co}, \mathrm{Zn}, \mathrm{As}, \mathrm{Br}$, $\mathrm{Rb}, \mathrm{Sr}, \mathrm{Sb}, \mathrm{Ba}, \mathrm{Tb}, \mathrm{Th}, \mathrm{U}$ were determined in the bacterial cells. The high rate of $\mathrm{Cr}$ accumulation in the tested bacterial cells was shown. In bacteria treated with chromate some similarity in the behaviour of the following essential elements - potassium, sodium, chlorine - was observed. Such non-essential elements as Ag, As, $\mathrm{Br}$ and $\mathrm{U}$ were determined in all bacteria and have to be considered by cells as toxins.
\end{abstract}

Keywords: neutron activation analysis, electron spin resonance spectrometry, Arthrobacter

\section{Introduction}

Environmental pollution by chromium is widespread in soils, sediments and groundwater [1]. Being a transition element, it occurs in a number of oxidation states from $\mathrm{Cr}(\mathrm{II})$ to $\mathrm{Cr}(\mathrm{VI})$. However, only two stable, trivalent and hexavalent, species are significant in environmental systems. Hexavalent chromium compounds are highly soluble and toxic [2]. Epidemiological, animal and cellular studies have also established that $\mathrm{Cr}(\mathrm{VI})$ compounds are carcinogenic [3]. In contrast to $\mathrm{Cr}(\mathrm{VI})$, most $\mathrm{Cr}(\mathrm{III})$ compounds are less soluble and less toxic. Moreover, trace amounts of $\mathrm{Cr}(\mathrm{III})$ appear to be essential for animal and human glucose and lipid metabolism. The biological effect of $\mathrm{Cr}(\mathrm{VI})$ is generally attributed to cellular uptake, because $\mathrm{Cr}(\mathrm{VI})$, unlike $\mathrm{Cr}(\mathrm{III})$, is easily uptaken by cells via $\mathrm{SO}_{4}{ }^{2-}$ and $\mathrm{HPO}_{4}^{2-}$ channels [4]. The toxicity of $\mathrm{Cr}(\mathrm{VI})$ compounds is ascribed to reactive intermediates (such as $\mathrm{Cr}(\mathrm{V})$, $\mathrm{Cr}(\mathrm{IV})$, radicals) generated during their reduction by living cells. Relatively, long-lived $\mathrm{Cr}(\mathrm{V})$ intermediates have been detected in the reduction of $\mathrm{Cr}(\mathrm{VI})$ both in vitro and in vivo [4,5]. However, to the best of our knowledge, there have been only a few studies that examined the in vivo formation of $\operatorname{Cr}(\mathrm{V})$ (in algae and fangs) $[5,6]$ and none on the dynamic detection of $\mathrm{Cr}(\mathrm{V})$ and its effect in bacteria. Toxic chromium compounds can be removed by chemical reduction, which is both difficult and expensive.

Indigenous bacteria can be successfully used to either detoxify or immobilize toxic heavy metals. These bacteria are under continuous investigation, and in-depth molecular understanding has been developed for some of them. However, up to date the dependence between the ability of bacteria to reduce or immobilize metals and their elemental compositions is not clear yet $[7,8]$.

In the present study the effect of $\mathrm{Cr}(\mathrm{VI})$ on the elemental content of these bacteria has been examined. Specifically, we tested three Gram-positive bacterial strains of Arthrobacter genera - A. oxydans (isolated in the USA from polluted Columbia basalt rocks), Arthrobacter sp. (61 B), and A. globiformis (151 B) (isolated from the most polluted regions in the Republic of Georgia).

\section{Materials and Methods}

\section{Sample cultivation and preparation for analysis}

The bacteria were grown aerobically in the following nutrient medium: $10 \mathrm{~g}$ of glucose, $10 \mathrm{~g}$ of peptone, $1 \mathrm{~g}$ of yeast extract, $2 \mathrm{~g}$ of caseic acid hydrolysate, $5 \mathrm{~g}$ of NaCl , and 1 liter of distilled water. To provide the chromium concentration of 35 and $200 \mathrm{mg} / \mathrm{L}, \mathrm{Cr}(\mathrm{VI})$ [as $\mathrm{K}_{2} \mathrm{CrO}_{4}$ ] was added to the nutrient medium at an early stationary phase of growth.

After being cultivated for 4 days the cells were harvested by centrifugation $\left(10,000 \mathrm{rpm}, 15 \mathrm{~min}, 4^{\circ} \mathrm{C}\right)$, rinsed twice in a $20 \mathrm{mM}$ phosphate buffer and analyzed by NAA method. 
To prepare bacterial samples for NAA, wet biomass was placed in an adsorption-condensation lyophilizer, dried, and pelletized to $5 \mathrm{~mm}$ pieces $(\sim 0.5 \mathrm{~g})$ by means of titanium press form.

\section{Instrumental Neutron Activation Analysis (INAA) at the reactor IBR-2}

ENAA was conducted at the IBR-2 pulsed fast reactor in FLNP, JINR, Dubna, which is characterized by a very high ratio $(\sim 100)$ of epithermal neutrons to thermal ones. The IBR-2 reactor provides activation with the whole fission spectrum: thermal, epithermal, and fast neutrons. Thermal NAA takes advantage of the high intensity of neutrons available from the thermalization of fission neutrons and the large thermal neutron cross sections for most isotopes.

Epithermal is taken to be neutrons with energies from the Cd "cutoff" of $0.55 \mathrm{eV}$ up to $\sim 1 \mathrm{MeV}$. ENAA is a useful extension of thermal (conventional) NAA in that it enhances the activation of a number of trace elements relative to the major matrix elements. ENAA is particularly advantageous for radionuclides produced from a stable isotope with a high resonance activation integral relative to its thermal neutron activation cross section. In general, the activation cross sections of the matrix elements of environmental samples are inversely proportional to the neutron energy $(1 / v$ law). The trace elements also follow this general trend, but many of them have large activation cross sections at specific energies in the epithermal energy region. In our case, the following advantages are evident: (i) improved detection limits for $\mathrm{As}, \mathrm{Br}, \mathrm{Rb}, \mathrm{Sr}$, and $\mathrm{Sb}$; (ii) reduction of high matrix activity, e.g., from ${ }^{28} \mathrm{Al},{ }^{56} \mathrm{Mn}$, ${ }^{24} \mathrm{Na},{ }^{46} \mathrm{Sc},{ }^{60} \mathrm{Co}$.

Bacterial samples of about $0.5 \mathrm{~g}$ were heat-sealed in polyethylene foil bags for short-term irradiation and for long-term irradiation were packed in aluminum cups. To determine the short-lived isotopes $\mathrm{Cu}, \mathrm{I}, \mathrm{Br}, \mathrm{Mn}, \mathrm{Mg}, \mathrm{Na}$, $\mathrm{V}, \mathrm{K}, \mathrm{Cl}$ and $\mathrm{Ca}$, channel 2(Ch2) was used. Samples were irradiated for 3 minutes and measured twice after $3-5$ and 20 minutes, respectively for 5 and 15 minutes. In case of long-lived isotopes of $\mathrm{Na}, \mathrm{K}, \mathrm{Sc}, \mathrm{Cr}, \mathrm{Fe}, \mathrm{Co}, \mathrm{Ni}, \mathrm{Zn}, \mathrm{As}$, $\mathrm{Se}, \mathrm{Br}, \mathrm{Rb}, \mathrm{Sr}, \mathrm{Ag}, \mathrm{Cd}, \mathrm{Sb}, \mathrm{Cs}, \mathrm{La}, \mathrm{Ce}, \mathrm{Sm}, \mathrm{Tb}, \mathrm{Yb}, \mathrm{Hf}, \mathrm{Au}$, Th and U, channel 1 (Ch1) was used. Samples were irradiated for five days, re-packed and then measured twice after 4-6 and 20 days, respectively. Measure time varied from 1-3 hours. $\gamma$-Ray spectra were measured using a large-volume $\mathrm{Ge}(\mathrm{Li})$ detector with a resolution of $1.96 \mathrm{keV}$ at the $1332.4-\mathrm{keV}$ line of ${ }^{60} \mathrm{Co}$ with an efficiency of $30 \%$ relative to a $3 \mathrm{in} . \times 3 \mathrm{in}$. NaI detector for the same line. The data processing and element concentration determination were performed on the basis of certified reference materials and comparators using software developed in FLNP JINR [9].

Three certified reference materials (CRMs), namely, IAEA Lichen-336, Donnye SL-1and Coal, fly ash SRM$1633 \mathrm{~b}$ were used for quality assurance purpose.

\section{Electron Spin Resonance Spectrometry}

The ESR investigations were carried out on a RE 1306 radiospectrometer with $100 \mathrm{kHz}$ modulation at $9.3 \mathrm{GHz}$ [10]. Detection of $\mathrm{Cr}(\mathrm{V})$ was carried out at liquid nitrogen temperature $(77 \mathrm{~K})$ to avoid a decrease in sensitivity of the ESR spectrometer caused by the water content in bacterial samples. The detection of the broad line for $\mathrm{Cr}$ (III) was complicated at low temperatures due to the presence of oxygen impurity in liquid nitrogen, which shifts the zero line. To avoid this problem, we measured $\mathrm{Cr}$ (III) at room temperature after drying the samples at $100{ }^{\circ} \mathrm{C}$. The typical settings for the registration of $\mathrm{Cr}(\mathrm{V})$ and $\mathrm{Cr}(\mathrm{III})$ are described in detail in [10].

\section{Results and discussions}

Metals play an integral role in life processes of microorganisms. In the present work, we focused on the determination of metal contents in bacteria cells. Some metals, such as $\mathrm{Co}, \mathrm{Cr}, \mathrm{Fe}, \mathrm{Na}, \mathrm{K}$, and $\mathrm{Zn}$, are required nutrients and are essential. Others have no definite biological function ( $\mathrm{Ag}, \mathrm{Al}, \mathrm{Cd})$ and are non-essential [11].

The concentrations from 12 to 19 elements such as $\mathrm{Na}, \mathrm{Al}, \mathrm{Cl}, \mathrm{K}, \mathrm{Fe}, \mathrm{Co}, \mathrm{Zn}, \mathrm{As}, \mathrm{Br}, \mathrm{Rb}, \mathrm{Sr}, \mathrm{Sb}, \mathrm{Ba}, \mathrm{Tb}, \mathrm{Th}$, and $\mathrm{U}$ were determined in the bacterial cells of 3 strains of Arthrobacter.

Data on chromium shows the high rate of $\mathrm{Cr}$ accumulation in tested bacterial cells (Fig.1). The chromium content in the control cells was less than $10 \mu \mathrm{g} / \mathrm{g}$, while the same values in the treated cells were much higher. For example, in Arthrobacter sp. it reached to $310^{3} \mu \mathrm{g} / \mathrm{g}$ after exposure to $35 \mathrm{mg} / \mathrm{L}$ of $\mathrm{Cr}(\mathrm{VI})$ for 4 days. Reduction of $\mathrm{Cr}(\mathrm{VI})$ to $\mathrm{Cr}(\mathrm{III})$ begins at the surface of bacteria with the formation of $\mathrm{Cr}(\mathrm{V})$ complexes (Fig.2) and the main part of reduced chromium ( $\mathrm{Cr}$ (III hydroxide) is tightly bound to bacterial cells. Our current ENAA data provide evidence that one part of chromium penetrates inside cells as well.

Bacteria can use chromium (VI) as terminal electron acceptor during oxidation of organic compounds. The capability of $\mathrm{Cr}(\mathrm{VI})$ reduction is not uncommon among $\mathrm{Cr}(\mathrm{VI})$-resistant microorganisms. Investigation of oxidationreduction potential (ORP) of nutrient medium during microbial chromate reduction has shown that $\mathrm{Cr}(\mathrm{VI})$ reduction takes place effectively at ORP level $+400-+200 \mathrm{mV}$. This is a potential range of aerobic processes. Standard 
electrode potential $\left(\mathrm{E}_{0}\right)$ of reaction: $\mathrm{Cr}_{2} \mathrm{O}_{4}{ }^{2-}+8 \mathrm{H}^{+}+3 \mathrm{e}=\mathrm{Cr}^{3+}+4 \mathrm{H}_{2} \mathrm{O}$ is $1477 \mathrm{mV}$. The potential is higher then potential of oxygen reduction process: $\mathrm{O}_{2}+4 \mathrm{H}^{+}+4 \mathrm{e}=2 \mathrm{H}_{2} \mathrm{O}\left(\mathrm{E}_{0}=1228 \mathrm{mV}\right)$. The reactions take place in bacterial cells during respiration. Therefore, the presents of oxygen is necessary to supply high OPR level in cultural medium. Thus, the reduction of $\mathrm{Cr}(\mathrm{VI})$ to $\mathrm{Cr}$ (III) has to take place in aerobic condition [12].

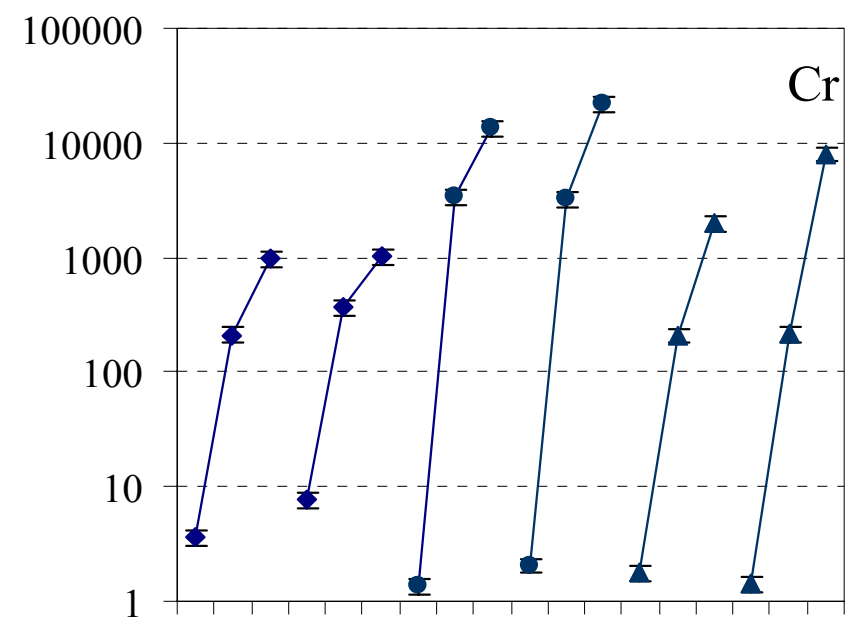

123123123123123123

Fig. 1. Concentration of chromium $(\mu \mathrm{g} / \mathrm{g})$ in different species of Arthrobacter: 1 - control; 2 - $35 \mathrm{mg} / \mathrm{L} \mathrm{Cr}(\mathrm{VI}) ; 3$ - $200 \mathrm{mg} / \mathrm{L} \mathrm{Cr}(\mathrm{VI})$

Arthrobacter oxydans

Artrobacter sp. (61B);

Arthrobacter globiformis (151B)

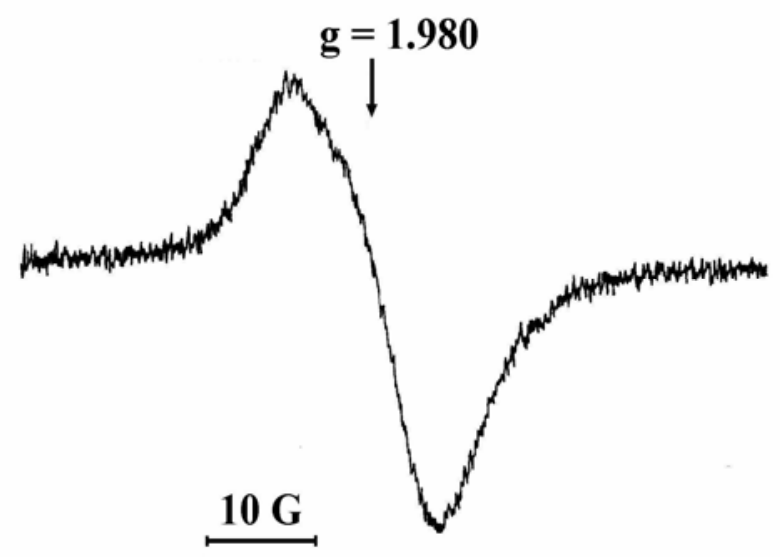

Fig. 2. An ESR spectrum of $\mathrm{Cr}(\mathrm{V})$ from tested bacteria after growing in the nutrient medium containing $\mathrm{Cr}(\mathrm{VI})$, line width $=12$ gauss and g-factor $=1.980$

In bacteria treated with chromate some similarity in the behaviour of the following essential elements potassium, sodium, chlorine - was observed (Fig. 3).

Potassium is known to play an important role in maintaining cellular osmotic pressure; it is involved in nonspecific activation of many enzymes, in bacterial energy metabolism (as the coupling ion), and in the regulation of intracellular pH. Potassium is the principal positively charged ion (cation) in the fluid inside of cells, while sodium is the principal cation in the fluid outside of cells. Potassium concentrations are about 30 times higher inside than outside cells, while sodium concentrations are more than ten times lower inside than outside cells.

The concentration differences between potassium and sodium across cell membranes create an electrochemical gradient known as the membrane potential. A cells membrane potential is maintained by ion pumps in the cell membrane, especially the sodium, potassium-ATPase pumps. These pumps use ATP (energy) to pump sodium out of the cell in exchange for potassium [11]. 
First, exposure to $\mathrm{Cr}(\mathrm{VI})$ caused a lower potassium concentrations in cells and the decrease of $\mathrm{K}$ content was almost equal at both low $(35 \mathrm{mg} / \mathrm{L})$ and high $(200 \mathrm{mg} / \mathrm{L})$ concentrations of $\mathrm{Cr}(\mathrm{VI})$. Second, concentrations of sodium and chlorine changed in a parallel way to each other, but in an opposite way to that of potassium. Decrease of $\mathrm{K}$ content, in other words extrusion of $\mathrm{K}$ from cells to maintain the acidity of their cytosol, concomitant with increase of $\mathrm{Na}$ (and correspondingly $\mathrm{Cl}$ ) content, suggests that, one part of $\mathrm{Cr}(\mathrm{V})$-diols (as well as $\mathrm{Cr}(\mathrm{VI})$ ions (via $\mathrm{HPO}_{4}{ }^{2-}$ channels)) were able to penetrate inside bacterial cells.

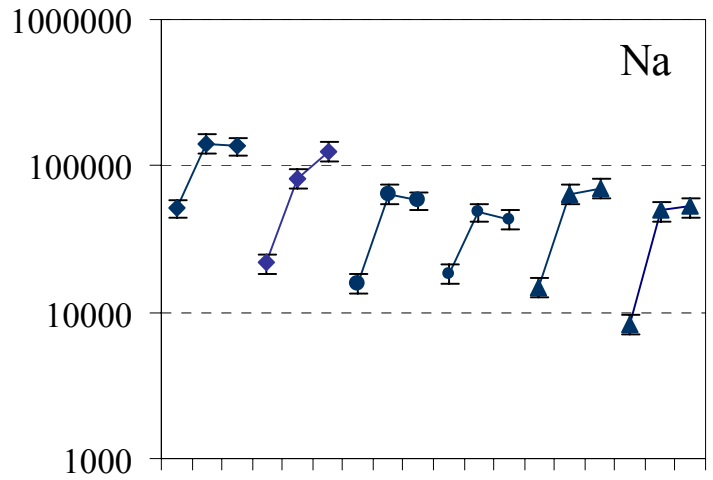

123123123123123123

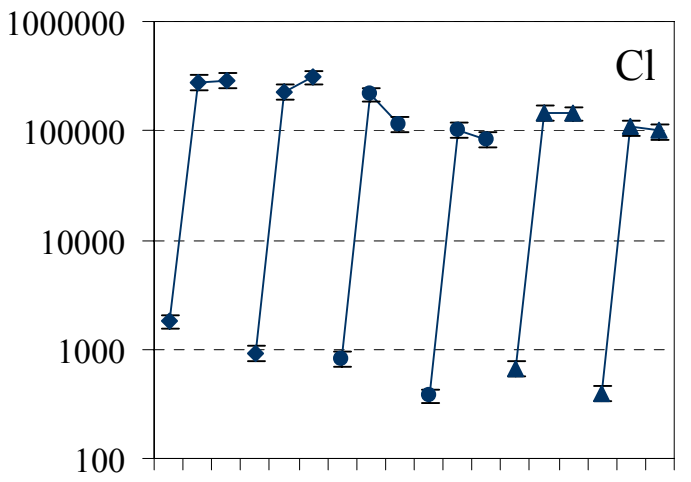

123123123123123123

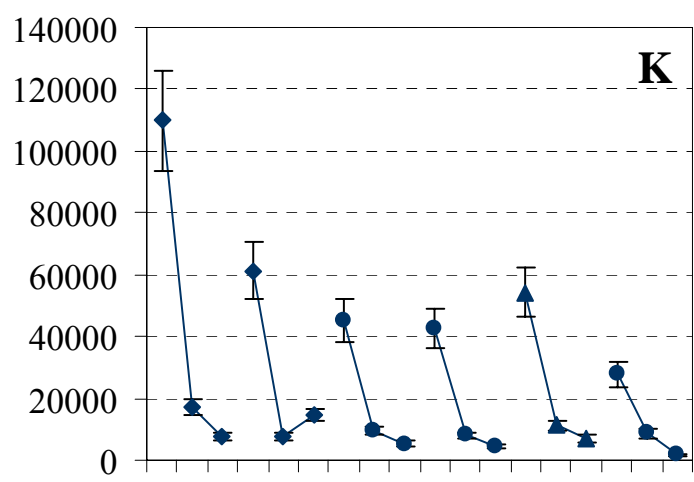

123123123123123123

Fig. 3. Concentration of $\mathrm{Na}, \mathrm{Cl}$ and $\mathrm{K}(\mu \mathrm{g} / \mathrm{g})$ in different species of Arthrobacter under different Cr(VI) loadings

NAA measurement of iron content in bacteria supports this conclusion (Fig. 4.). As is known, iron is the most important metal biologically. It is a many-functional constituent ofcomplex molecules. Fig. 4 demonstrates that in the tested bacteria the Fe content significantly increased in response to $\mathrm{Cr}(\mathrm{VI})$ loading, indicating that the bacterial protective system was activated significantly against chromium toxic impact.

In A. globiformis, contrary to A. oxydans and Arthrobacter sp, the content of iron increased almost linearly with increase of $\mathrm{Cr}(\mathrm{VI})$ dose. It seems that $\mathrm{Cr}(\mathrm{VI})$ transformation mechanism is rather different in $A$. globiformis than in Arthrobacter oxydans and Arthrobacter sp.

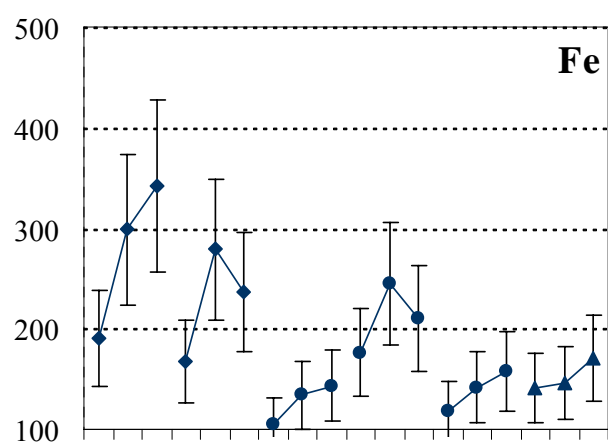

123312312231223123123

Fig. 4. Concentration of $\mathrm{Fe}(\mu \mathrm{g} / \mathrm{g})$ in different species of Arthrobacter under different $\mathrm{Cr}(\mathrm{VI})$ loadings 
This result suggests what the chemical composition of basalts influenced the elemental composition of bacteria. Really the Georgian basalt samples from the studied sites are rocks with high content of total iron $\left(\mathrm{Fe}_{2} \mathrm{O}_{3}+\mathrm{FeO}\right)$, which is due to the abundance of ferromagnesial minerals-pyroxenes $\left[(\mathrm{Ca}, \mathrm{Na}, \mathrm{Mg}, \mathrm{Fe})(\mathrm{Al}, \mathrm{Si}) \mathrm{O}_{3}\right]$, olivine $\left(\mathrm{Mg}_{1.8} \mathrm{Fe}_{0.2} \mathrm{SiO}_{4}\right)$, magnetite $\left.\left(\mathrm{Fe}^{2+} \mathrm{Fe}_{2}{ }^{3+}\right) \mathrm{O}_{4}\right)$. Ferrous monoxide form is predominant in all samples $(\mathrm{FeO}=4.2-$ $8.4 \%$ ), while ferrous oxide is also present in quantity $\left(\mathrm{Fe}_{2} \mathrm{O}_{3}=3.0-5.9 \%\right.$ of iron) [13].

$\mathrm{As}, \mathrm{Br}, \mathrm{Nd}, \mathrm{Rb}, \mathrm{Sb}, \mathrm{U}$ were also determined in all bacteria (Fig. 5). These non-essential elements have no beneficial function and have to be considered by cells as toxins, however their behavior illustrates that the permeability of bacterial cell wall changed after treatment with chromium.

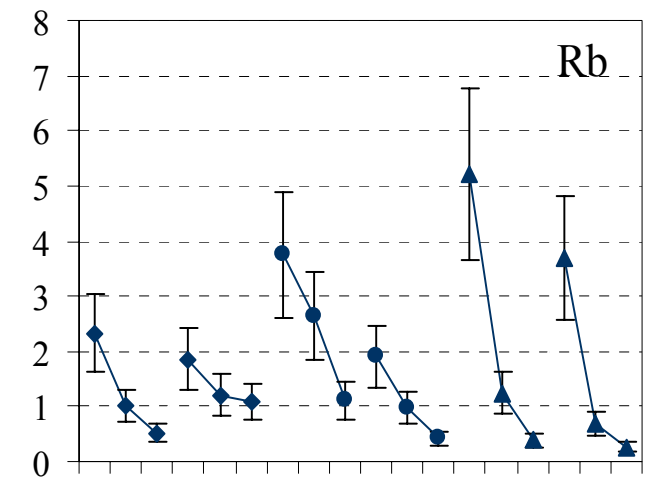

12312231231223123123

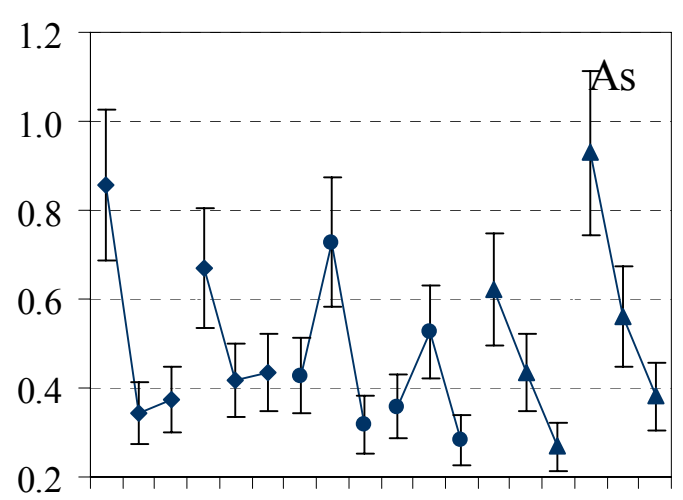

12312331231231223123

Fig.5. Concentration of As and Rb $(\mu \mathrm{g} / \mathrm{g})$ in different species of Arthrobacter under different $\mathrm{Cr}(\mathrm{VI})$ loadings

\section{Conclusions}

- By application of INAA and ESR spectrometry the behavior of chromium in basalt-inhabiting bacteria of Arthrobacter genera exposed to high concentrations of $\mathrm{Cr}(\mathrm{VI})$ was studied. It was shown that the tested bacteria of Arthrobacter genera can efficiently detoxify high concentrations of Cr(VI).

- The concentrations of 12-19 elements were determined in each bacterium simultaneously. The concentration range was over 8 orders of magnitude, from major- to ultra trace elements. Some similarity in the elemental composition of bacteria was observed.

- In all bacteria, potassium and sodium were the dominant elements. The concentrations of both $\mathrm{Na}$ and $\mathrm{K}$ were in the range of $10^{5} \mu \mathrm{g} / \mathrm{g}$. In the tested bacteria the concentrations of the other elements were much less.

- The relatively high contents of Fe detected in bacteria indicate bacterial adaptation to the environmental conditions typical for basalts.

- Elemental analysis of these bacteria also revealed that basalt-inhabiting bacteria are distinguished by relative contents of essential metals such as $\mathrm{Na}, \mathrm{K}, \mathrm{Fe}, \mathrm{Zn}, \mathrm{Co}$.

\section{References}

[1]. Cary, E. E. Chromium in air, soils and natural waters, in Biological and Environmental Aspects of Chromium, S. LANGARD (Ed.), Elsevier, Amsterdam, the Netherlands, 1989.

[2]. Langard, S. The carcinogenicity of chromium compound in men and animals, in: Chromium Metabolism and Toxicity, S. Borrow (Ed.), CRS Press, 1983.

[3]. Deflora, S.; Wetterhahn, K. E. Life Chem. Rep., 7 (1989) 169.

[4]. Codd, R.; Dillon, C. T.; Levina A.; Lay, P. A. Coord. Chem. Rev., 216.217 (2001) 537.

[5]. Appenroth, K. Y.; Bischoff, M.; Gabrys, H.; Stoeckel, J.; Swartz, H. M.; Walczak, T.; Winnefeld, K. J. Inorg. Biochem., 78 (2000) 235.

[6]. Liu, K. J.; Jiang, J. J.; Shi, X. Biochem. Biophys. Res. Commun., 206 (1995) 829.

[7]. Lloyd, J. R. Microbiology Today. 2002, V. 29, p. 67.

[8]. Rudic V.; Dencicov L. Microbiologie genetrală, manulal pentru studenții ciclului universitar, Centrul editorial USM, 2002.

[9]. Ostrovnaya, T. M.; Nefedyeva, L. S.; Nazarov, V. M.; Borzakov, S. B.; Strelkova, L. P. Proceedings, Activation Analysis in Environment Protection, Dubna, 1993; p 319, preprint D-14-93-325 
[10]. Kalabegishvili, T.; Tsibakhashvili, N.; Holman, H.-Y. Environ. Sci. Technol. 2003, 37, 4678-4684.

[11]. Hoghes M. N.; Peele R. K. Metals and Microorganisms, Chapman and Hall, 1989.

[12]. Dmytrenko G.M.; Ereshko T.V.; Konovalova V.V. Reduction of Chromium (VI) by bacteria collection strains of different physiological groups, Microbiology, 6 .2007, 125-130

[13]. Tsibakhashvili N.; Frontasyeva M. V.; Kirkesali E.; Aksenova N.; Kalabegishvili L.; Mosulishvili L.; Tsertsvadze T.; Holman H-Y. Epithermal neutron activation analysis of $\mathrm{Cr}(\mathrm{VI})$-reducer basalt-inhibiting bacteri, Jornal of analytical chemistry, 2005, vol.53. 